\title{
PERANCANGAN APLIKASI GAME EDUKASI UNTUK PEMBELAJARAN BAHASA TERNATE PADA ANAK-ANAK
}

\section{DESIGNING EDUCATIONAL GAMES APPLICATIONS FOR LANGUAGE LEARNING OF TERNATE IN CHILDREN}

\author{
Sary Noviyanti \\ Fakultas Teknik, Prodi Teknik Informatika \\ Universitas Khairun Ternate \\ novasary.sn@gmail.com
}

\begin{abstract}
Abstrak
Pembuatan game ini menggunakan metode prototyping, tahapan metodenya dimulai dari perencanaan, analisa, desain, implementasi dan pengujian. Pembuatan game ini menggunakan aplikasi Macromedia Flash 8, didukung oleh Photoshop CS3 untuk pembuatan latar hingga button dan kemudian di ekspor ke macromedia flash 8 untuk menyempurnakan game tersebut. Pembuatan game disesuaikan dengan kriterian dan umur si pengguna, game ini memiiliki tampilan yang userfriendly serta pilihan tingkat kesulitan yang berbeda-beda yaitu level mudah, sedang dan sulit serta mempunyai materi pembelajaran yang dilengkapi dengan suara. Pengujian menggunakan black box yang diawali dari halaman awal hingga pengujian skor, disetiap form terdapat button yang bila diklik akan menuju ke tampilan selanjutnya, Pengujian juga dilakukan dengan menguji langsung pada anak-anak dengan kisaran usia rata-rata 10 tahun, hasil yang di dapat dari pengujian game yaitu kebanyakkan dari mereka berhasil menyelesaikan soal dari waktu yang ditetapkan, dibuktikan dengan skor yang didapat diatas 70 yang artinya game ini dapat membantu anakanak dalam mempelajari bahasa daerah Ternate. Dengan adanya aplikasi game edukasi untuk pembelajaran bahasa Ternate pada anak-anak ini diharapkan dapat membantu dalam meningkatkan pengetahuan anak dalam mengenal bahasa daerah ternate
\end{abstract}

\section{Kata kunci: Game Edukasi, Bahasa Ternate, Macromedia Flash 8, Photoshop CS3}

\begin{abstract}
The making of this game using the method of prototyping, the stages of his start from the planning, analysis, design, implementation, and testing. The making of this game using Macromedia Flash 8 application, supported by Photoshop CS3 for manufacturing background to button and then export to MacromediaFlash 8 to fine-tune the game. The making of the game adapted to the criteria and the age of the user, This game has a userfriendly display as well as the choice of different difficulty levels, level easy, medium and hard, learning material and which are equipped with sound, Using black box testing that begins from the start page to test score every form there is a button that when clicked will be heading to the next display. Testing is also done by testing directly on children with the range of the average age of 10 years, results from testing a game that is a few of them managed to solve at the time that has been set, evidenced by the obtained score above 70, meaning this game can assist children in learning the local languages of Ternate. With the application of
\end{abstract}


educational game for learning the language of Ternate in children, expected to help in improving the knowledge of the child in getting to know local languages of Ternate

Keywords: Game Education, Ternate Language, Macromedia Flash 8, Photoshop CS3

\section{PENDAHULUAN}

Bahasa dapat diartikan sebagai alat Untuk menyampaikan sesuatu yang terlintas di dalam hati. Namun, lebih jauh bahasa adalah alat untuk berinteraksi atau alat untuk berkomunikasi, dalam arti alat untuk menyampaikan pikiran, gagasan, konsep atau perasaan. Sedangkan pada bahasa daerah ialah suatu penuturan yang dipergunakan untuk berinteraksi antar daerah tertentu saja, sehingga tidak memungkinkan daerah lain untuk mengerti akan apa yang tidak di mengerti daerah lainnya.

Bahasa Ternate merupakan salah satu bahasa daerah di provinsi Maluku Utara yang digunakan sebagai alat komunikasi untuk menyampaikan informasi, melakukan transaksi di pasar maupun berkomunikasi dirumah atau dimana saja, Seiring dengan berjalanannya waktu bahasa daerah Ternate sudah mulai hilang dan jarang digunakan sebagai alat komunikasi terutama anak-anak yang belajar bahasa daerah ternate pada mata pelajaran yang hanya ajarkan disekolah saja dan sekolah mempunyai waktu yang sangat terbatas dalam mempelajari bahasa daerah ternate tersebut sehingga pengetahuan anak dalam mengenal bahasa daerah ternate sangat kurang

Sebagai anak bangsa baiknya diperkenalkan sejak dini pengetahuan tentang bahasa daerah Ternate agar kelak dapat mempertahankan serta menjaga bahasa daerah tersebut karena sebagai satu ciri khas dari daerah Ternate. Oleh karena itu, diperlukan suatu media dimana dapat membantu memperkenalkan bahasa daerah pada anak-anak. Dengan berkembangnya teknologi saat ini bermunculan berbagai jenis game yang mengandung unsur edukasi.

Game Edukasi merupakan salah satu teknologi informasi yang bisa dimanfaatkan sebagai sarana pembelajaran dimana prosesnya dapat dilakukan dengan konsep belajar sambil bermain. Teknologi tersebut dapat dijadikan pilihan untuk para orang tua untuk memperkenalkan bahasa daerah Ternate. Sehingga atas dasar itulah timbul ide menyelesaikan masalah tersebut dengan membangun aplikasi yang memberikan pengenalan tentang bahasa daerah Ternate, Dengan adanya aplikasi game edukasi untuk pembelajaran bahasa Ternate pada anak-anak ini diharapkan dapat membantu dalam meningkatkan pengetahuan anak dalam mengenal bahasa daerah ternate.

\section{Rumusan Masalah}

Berdasarkan uraian latar belakang masalah sebelumnya maka dalam penelitian ini dapat dirumuskan masalah yaitu: Bagaimana Merancang Aplikasi Game Edukasi Untuk Pembelajaran Bahasa Ternate Pada Anak-anak menggunakan aplikasi Macromedia Flash 8 dan Photoshop CS3

\section{LANDASAN TEORI Pengertian Software}

Software atau perangkat lunak komputer merupakan istilah khusus untuk data yang diformat serta disimpan dalam bentuk secara digital, termasuk didalamnya program-program komputer, dokumentasi, berbagai informasi yang dapat dibaca serta ditulis oleh komputer. 
Dengan kata lain, software atau perangkat lunak komputer merupakan salah satu bagian sistem komputer, namun software tidak berwujud. Berbeda dengan perangkat keras atau hardware. Pengertian software adalah sekumpulan data - data elektronik yang disimpan serta diatur oleh komputer. Data-data elektronik yang disimpan tersebut dapat berupa program ataupun instruksi yang akan menjalankan berbagai macam perintah.

\section{Game Edukasi}

Game edukasi adalah permainan yang dirancang atau dibuat untuk merangsang daya pikir termasuk meningkatkan konsentrasi dan memecahkan masalah. Game edukasi adalah salah satu jenis media yang digunakan untuk memberikan pengajaran, menambah pengetahuan penggunanya melalui suatu media unik dan menarik. Game jenis ini biasanya ditujukan untuk anak-anak, maka permainan warna sangat diperlukan disini bukan tingkat kesulitan yang dipentingkan. Berdasarkan uraian tersebut maka dapat disimpulkan game edukasi adalah salah satu bentuk game yang dapat berguna untuk menunjang proses belajar-mengajar secara lebih menyenangkan dan lebih kreatif, dan digunakan untuk memberikan pengajaran atau menambah pengetahuan penggunanya melalui suatu media yang menarik (Putri, 2012).

\section{Bahasa Indonesia}

Bahasa Indonesia adalah bahasa resmi Republik Indonesia dan bahasa persatuan bangsa Indonesia. Bahasa Indonesia diresmikan penggunaannya setelah Proklamasi Kemerdekaan Indonesia, tepatnya sehari sesudahnya, bersamaan dengan mulai berlakunya konstitusi. Di Timor Leste, Bahasa Indonesia berstatus sebagai bahasa kerja. Dari sudut pandang linguistik, Bahasa Indonesia adalah salah satu dari banyak ragam bahasa Melayu. Dasar yang dipakai adalah bahasa Melayu Riau (Wilayah Kepulauan Riau sekarang) dari abad ke- 19. Dalam perkembangannya ia mengalami perubahan akibat penggunaanya sebagai bahasa kerja di lingkungan administrasi kolonial dan berbagai proses pembakuan sejak awal abad ke-20.

\section{Bahasa Daerah Ternate}

Bahasa-bahasa daerah diIndonesia mempunyai pengaruh dalam pembentukan dan pengembangan Bahasa Indonesia. Sebelum mengenal Bahasa Indonesia sebagian besar bangsa Indonesia mempelajari dan menggunakan bahasa daerah dalam interaksi kehidupan masyarakat. Ucapan dan cara penyampaian ide-ide dipengaruhi kebiasaan yang lazim digunakan oleh masyarakat tersebut. Bahasa daerah tetap dipelihara oleh negara sebagai bagian kebudayaan yang hidup. Bahasa Ternate merupakan salah satu bahasa daerah di Indonesia yang masih digunakan oleh masyarakat pendukungnya dalam kehidupan berinteraksi sehari-hari. Bahasa ini dapat dikatakan sebagai bahasa pertama dalam komunikasi sosial dari berbagai lapisan masyarakat Ternate asli. Bahasa Ternate yang diketahui terdiri atas beberapa dialek, di antara dialek tersebut masih berperan di dalam kehidupan masyarakat sehari-hari, misalnya dengan ucapan, kegiatan kemasyarakatan dan interaksi sosial berlangsung dengan menggunakan bahasa Ternate, baik di tempat asal penutur di Kota Ternate maupun di daerah lainnya di tempat perantauan mereka. Di daerah Ternate hanya di bagian Selatan kota dan Utara kota yang masih menggunakan bahasa 
Ternate untuk berkomunikasi sehari-hari, contohnya kelurahan Kastela, Rua, Durpedu, Togafo, Dufa-Dufa, Akehuda, Sango, dll.

\section{Anak-Anak}

Anak merupakan cikal bakal lahirnya suatu generasi baru yang merupakan penerus cita-cita perjuangan bangsa dan sumber daya manusia bagi pembangunan nasional. Anak adalah aset bangsa. Masa depan bangsa dan negara dimasa yang akan datang berada ditangan anak sekarang. Semakin baik keperibadian anak sekarang maka semakin baik pula kehidupan masa depan bangsa. Begitu pula sebaliknya, apabila keperibadian anak tersebut buruk maka akan hancur pula kehidupan bangsa yang akan datang. Adapun yang dimaksud dengan anak disini adalah orang yang berusia 5-11 tahun atau disebut masa usia sekolah dasar/usia kanak-kanak akhir, pada usia ini juga disebut sebagai masa berkelompok dan masa intelektual. Anak mulai menguasai keahlian membaca, menulis, dan berhitung. Prestasi menjadi keahlian utama dari kehidupan anak dan mereka semakin mampu mengendalikan diri. Dalam periode ini, mereka berinteraksi dengan dunia sosial yang lebih luas diluar keluarga. Masa ini juga disebut masa untuk matang belajar, anak tersebut sudah merasa besar dan tidak mau lagi sebagai kanak-kanak kecil. Anak tersebut sudah terlepas dari lembaga pendidikan dasar / taman kanak - kanak.

\section{Macromedia Flash 8}

Macromedia Flash 8, merupakan software yang dirancang untuk membuat animasi berbasis vektor dengan hasil yang mempunyai ukuran yang kecil dibanding file video. Awalnya software ini memang diarahkan untuk membuat animasi atau aplikasi berbasis internet (online). Tetapi pada perkembangannya banyak digunakan untuk membuat animasi atau aplikasi yang bukan berbasis internet (offline). Dengan Actionscript yang dibawanya, flash dapat digunakan untuk mengembangkan game atau bahan ajar seperti kuis atau simulasi (Putri, 2012). Maromedia Flash, sebagai program multimedia dan animasi, mempunyai beberapa kelebihan dibandingkan dengan program animasi lainnya.

\section{Manajemen Pengembangan Perangkat Lunak}

Dalam pembangunan proyek prangkat lunak pastinya ada hal-hal yang menentukan apakah proyek akan berjalan dengan yang diharapkan sehingga menghasilkan kualitas yang baik. Bagian penting tersebut adalah Manajeman Proyek Perangkat lunak. Definisi manajemen proyek perangkat lunak itu sendiri yaitu aktifitas perancangan dan pengontrolan membuat prangkat lunak dalam jangka waktu tertentu untuk memenuhi kebutuhan. Manajemen proyek perangkat lunak mengatur 4 hal penting yaitu personel, produk, proses dan proyek. Dari empat hal tersebut personel merupakan hal yang terpenting, karena personel adalah aktor yang mengisi pembangunan perangkat lunak dengan adanya personel atau orang-orang yang berperan didalamnya itu baik atau mempunyai kemampuan / skill bagus, maka produk yang dihasilakan, proses yang berjalan, dan proyek yang dikerjakan akan baik/bagus juga.

\section{Prototyping}

Proses pengembangan sistem seringkali menggunakan pendekatan 
prototipe (prototyping). Metode ini sangat baik digunakan untuk menyelesesaikan masalah kesalahpahaman antara user dan analis yang timbul akibat user tidak mampu mendefinisikan secara jelas kebutuhannya. Prototyping adalah pengembangan yang cepat dan pengujian terhadap model kerja (prototipe) dari aplikasi baru melalui proses interaksi dan berulang-ulang yang biasa digunakan ahli sistem informasi dan ahli bisnis. Prototyping disebut juga desain aplikasi cepat (Rapid Application Design) karena menyederhanakan dan mempercepat desain sistem. Sebagian user kesulitan mengungkapkan keinginannya untuk mendapatkan aplikasi yang sesuai dengan kebutuhannya. Kesulitan ini yang perlu diselesaikan oleh analis dengan memahami kebutuhan user dan menerjemahkannya ke dalam bentuk model (prototipe). Model ini selanjutnya diperbaiki secara terus menerus sampai sesuai dengan kebutuhan use

\section{Flowchart}

Flowchart merupakan gambar atau bagan yang memperlihatkan urutan dan hubungan antar proses beserta instruksinya. Gambaran ini dinyatakan dengan simbol. Dengan demikian setiap simbol menggambarkan proses tertentu. Sedangkan hubungan antar proses digambarkan dengan garis penghubung. Flowchart ini merupakan langkah awal pembuatan program. Dengan adanya flowchart urutan poses kegiatan menjadi lebih jelas. Jika ada penambahan proses maka dapat dilakukan lebih mudah. Setelah flowchart selesai disusun, selanjutnya pemrograman (programmer) menerjemahkannya ke bentuk program dengan bahsa pemrograman. Dalam pembuatan flowchart tidak ada rumus atau patokan yang bersifat mutlak. Karena flowchart merupakan gambaran hasil pemikiran dalam menganalisa suatu masalah dengan komputer. Sehingga flowchart yang dihasilkan dapat bervariasi antara satu pemrogram dengan pemrogram lainnya

\section{Blackbox}

Pengujian sistem yang digunakan untuk menguji adalah metode pengujian Black Box. Pengujian Black box berfokus pada persyaratan fungsional perangkat lunak. Metode pengujian Black Box digunakan untuk menguji sistem dari segi user yang dititik beratkan pada pengujian kinerja, spesifikasi dan antarmuka sistem tersebut tanpa menguji kode program yang ada. Berbeda dengan White Box testing, black box testing tidak membutuhkan pengetahuan mengenai, alur internal (internal path), struktur atau implementasi dari Software Under Test (SUT). Karena itu uji coba black box memungkinkan pengembang software untuk membuat himpunan kondisi input yang akan melatih seluruh syarat-syarat fungsional suatu program. Uji coba Black Box bukan merupakan alternatif dari uji coba White Box, tetapi merupakan pendekatan yang melengkapi untuk menemukan kesalahan lainnya, selain menggunakan metode white box testing. Black Box Testing dapat dilakukan pada setiap level pembangunan sistem. Mulai dari Unit, Integration, System, dan Acceptance.

\section{METODE PENELITIAN}

\section{Metode Pengembangan Sistem}

Pengembangan Game Edukasi yang dibuat menggunakan metode Prototyping. Metode Prototyping merupakan salah satu metode pengembangan perangat lunak yang banyak digunakan. Proses

Volume 2 Nomor 2 | April 2017 
pengembangan sistem seringkali menggunakan pendekatan prototipe (prototyping). Metode ini sangat baik digunakan untuk menyelesesaikan masalah kesalahpahaman antara user dan analis yang timbul akibat user tidak mampu mendefinisikan secara jelas kebutuhannya.

Tahapan Perancangan Game Sebagai berikut:

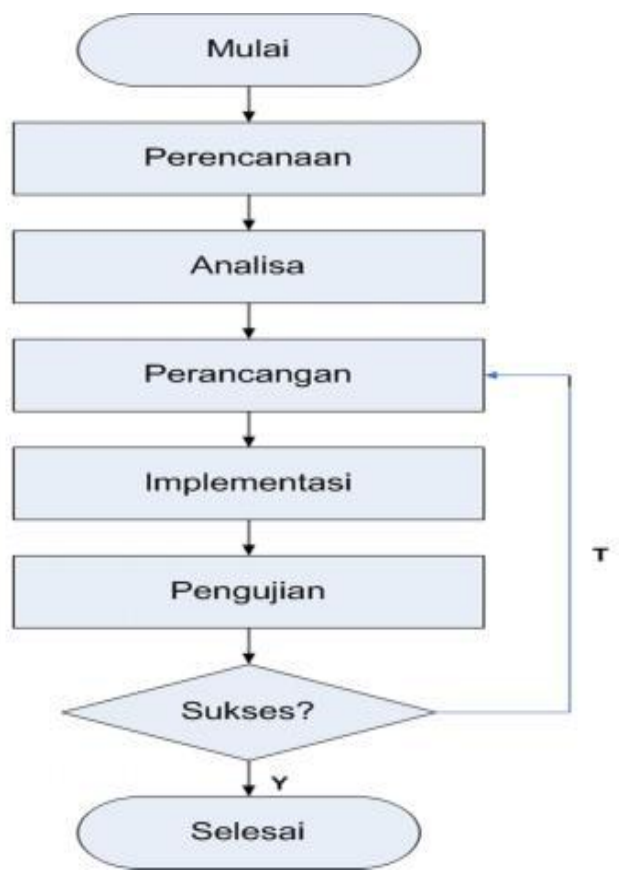

Gambar 1. Tahapan Rancangan Game

\section{Kebutuhan Fungsional}

Kebutuhan fungsional pada rancangan game edukasi ini adalah Dimana admin dapat login pada sistem dan mengelola data game pada sistem, anak-anak dapat mengunakan game tersebut sebagai edukasi bahasa daerah ternate.

\section{Kebutuhan Non-Fungsional}

Merupakan kebutuhan perangkat perangkat yang mendukung dalam pembuatan sistem informasi di antaranya:

1. Perangkat Keras (Hardware)

\begin{tabular}{|l|l|l|}
\hline No & Alat/Perangkat & Spesifikasi \\
\hline 1 & Processor & $2 \mathrm{GHz}$ \\
\hline 2 & Memory (RAM) & Minimum 2 GB \\
\hline 3 & Monitor & 14 \\
\hline 4 & Keyboard & Standar \\
\hline
\end{tabular}

\begin{tabular}{|l|l|l|}
\hline 5 & Mouse & Standar \\
\hline
\end{tabular}

2. Perangkat lunak (Software)

Perangkat lunak yang digunakan untuk mendukung dan merancang pembuatan Game Edukasi adalah sebagai berikut:

a. Sistem operasi Windows 7 Ultimate

b. Macromedia Flas 8

c. Adobe Photoshop CS3

d. Microsoft Visio untuk desain sistem

\section{PERANCANGAN SISTEM \\ Flowchart Game \\ Tampilan Awal}

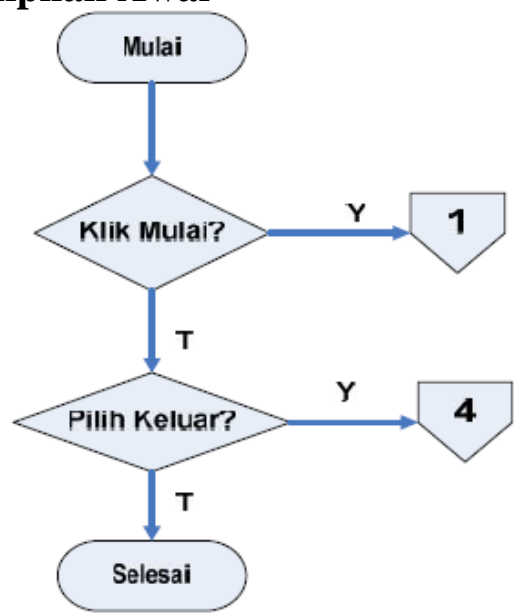

Gambar 2. Flowchart Tampilan Awal

Ket: $\quad 1=$ Lanjut ketampilan kedua

4 = Lanjut ketampilan kelima

\section{Tampilan Kedua}

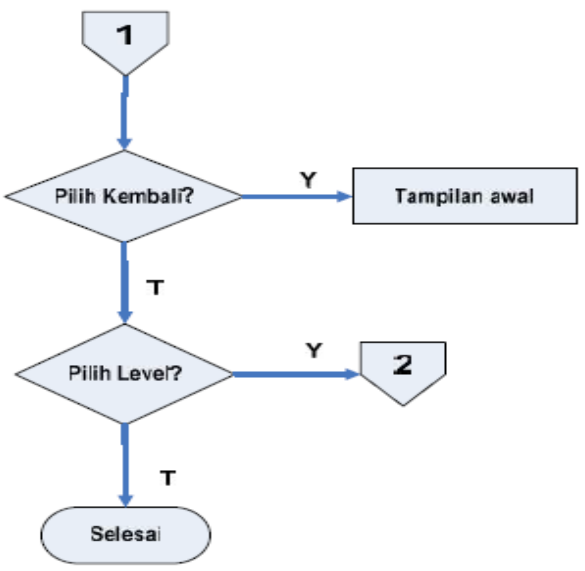

Gambar 3. Flowchart Tampilan Kedua 
Ket: 2 = Lanjut ketampilan ketiga

\section{Tampilan Ketiga}

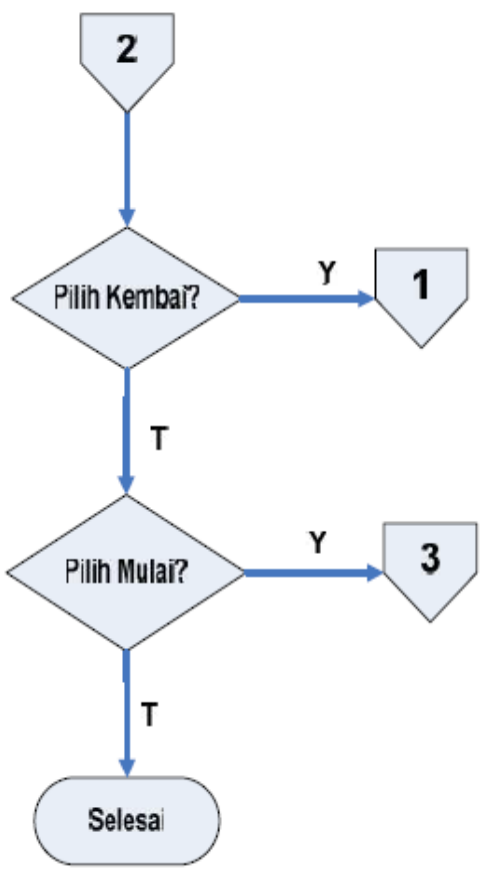

Gambar 4. Flowchart Tampilan Ketiga

Ket : $\quad 1=$ Ketampilan kedua

$3=$ Lanjut ketampilan keempat

\section{Tampilan Keempat}

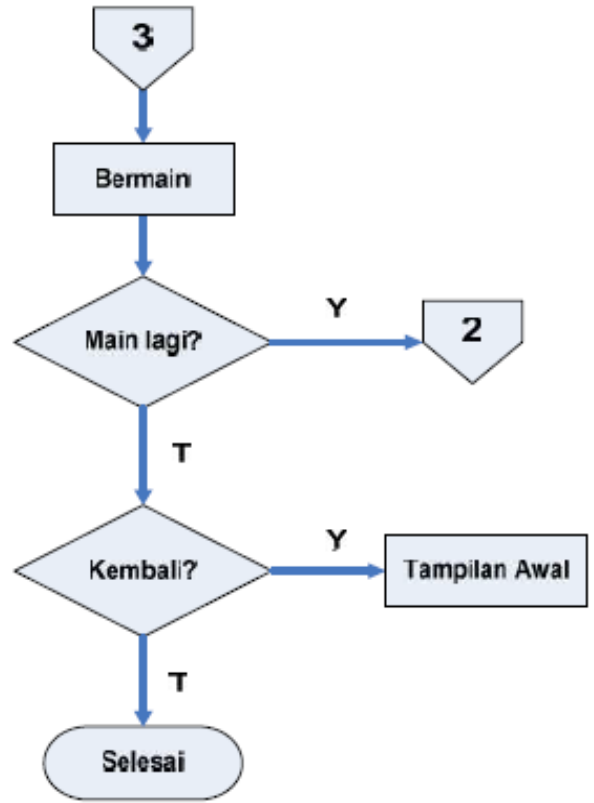

Gambar 5. Flowchart Tampilan Keempat Ket: $2=$ Ketampilan ketiga

\section{Tampilan Kelima}

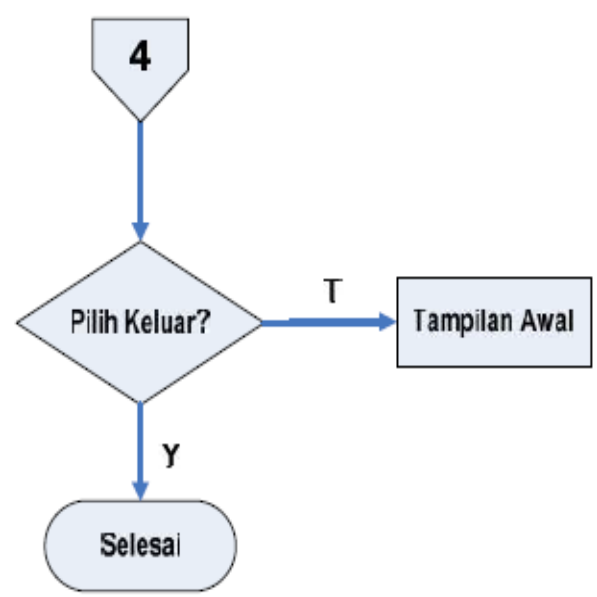

Gambar 6. Flowchart Tampilan Kelima

\section{Blok Diagram}

Berikut adalah blok diagram dari edukasi game yang merupakan gambaran umum cara kerja sistem perangkat lunak. Aplikasi game ini akan dibagi-bagi lagi ke dalam beberapa tahapan proses. Jika digambarkan dalam bentuk diagramnya akan tampak seperti pada gambar berikut:

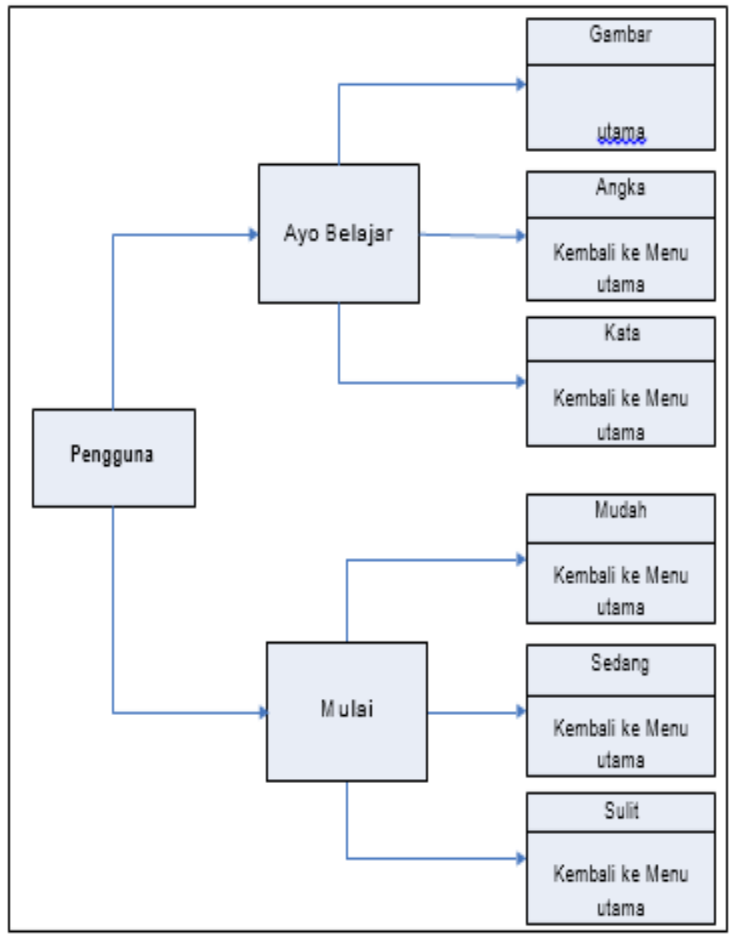

Gambar 6. Blok Diagram Rancangan Game 


\section{Diagram Blok Umum Level Game}

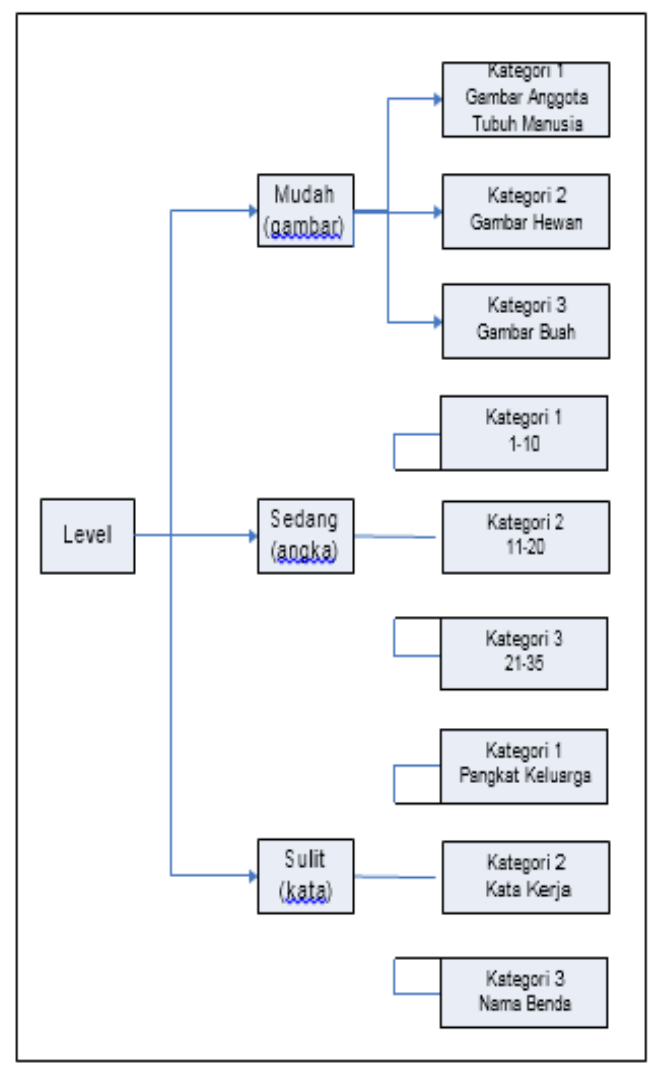

Gambar 7. Rancangan Blok Level Game

\section{Rancangan Interface Education Game}

Rancangan Interface merupakan bentuk rancangan tampilan dari sistem yang akan dibuat nanti, berikut merupakan rancangan interface game edukasi

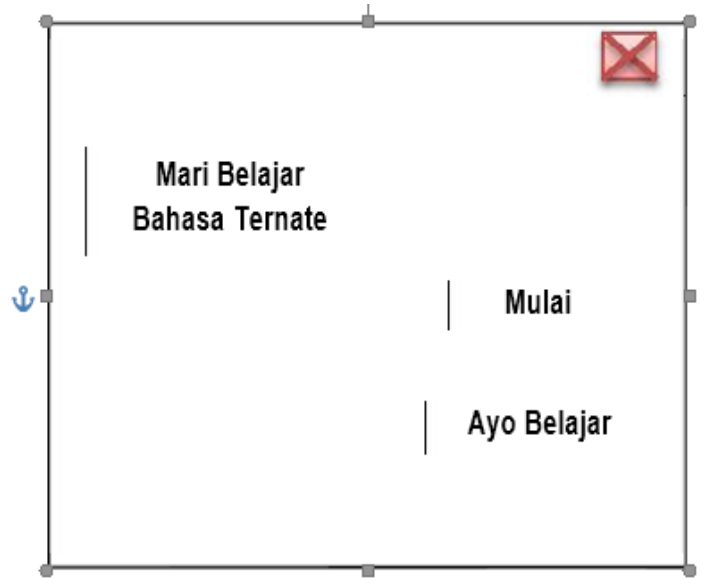

Gambar 8. Rancangan Interface Game

\section{Rancangan Interface Home}

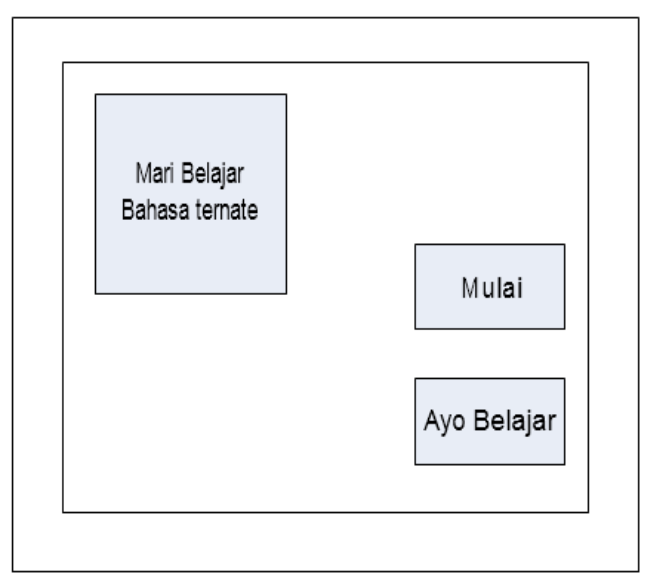

Gambar 9. Rancangan Interface Home

\section{Rancangan Interface Ayo Belajar}

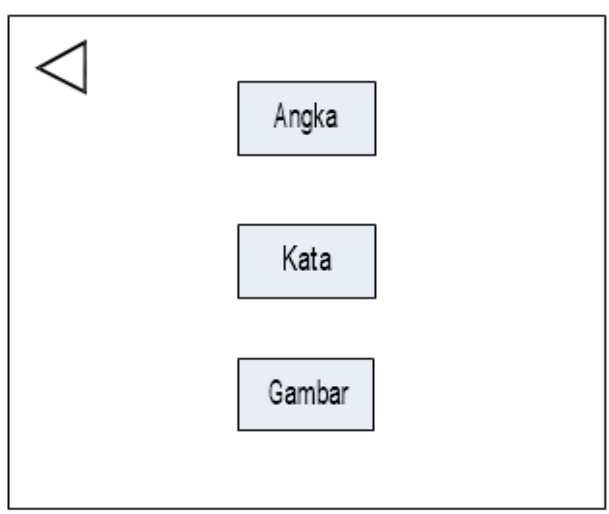

Gambar 10. Rancangan Interface Ayo Belajar

\section{Rancangan Interface Pilih Level}

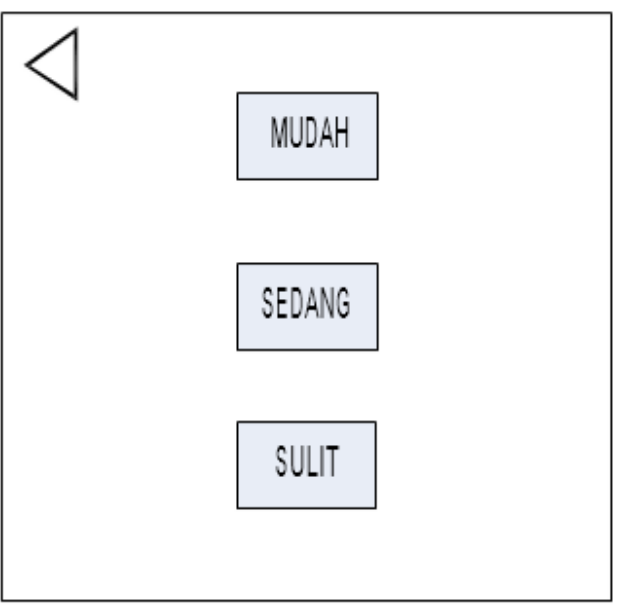

Gambar 11. Rancangan Interface Pilih Level 
Rancangan Interface Pilih Kategori

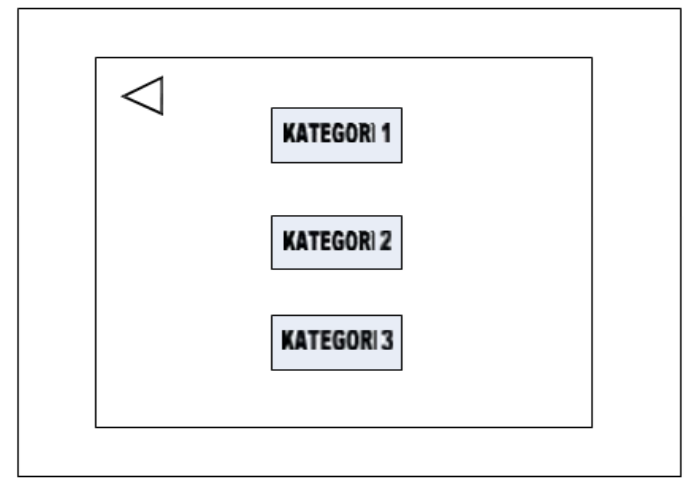

Gambar 11. Rancangan Interface Pilih Kategori

\section{Rancangan Interface Score}

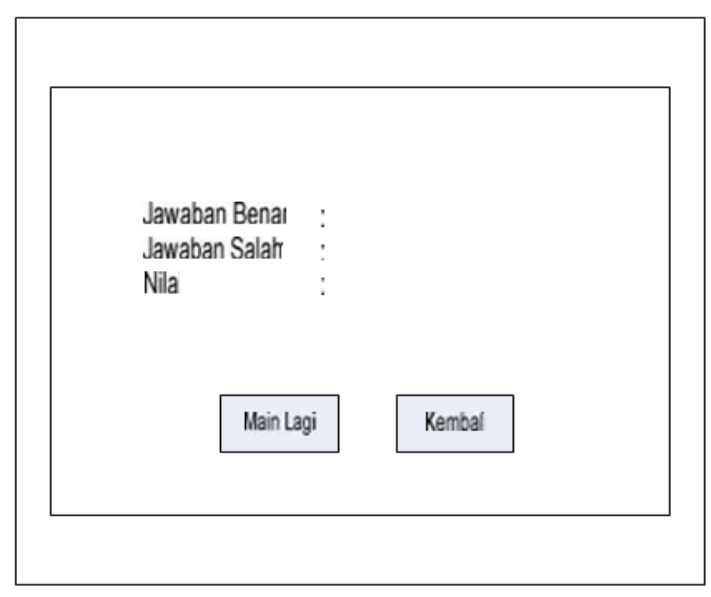

Gambar 12. Rancangan Interface Score Rancangan Interface Form Keluar

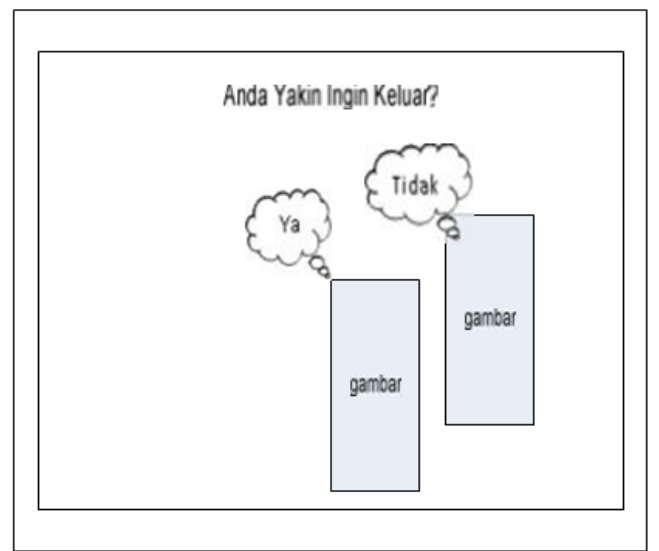

Gambar 13. Rancangan Interface Form Keluar
IMPLEMENTASI SISTEM

Tampilan Home

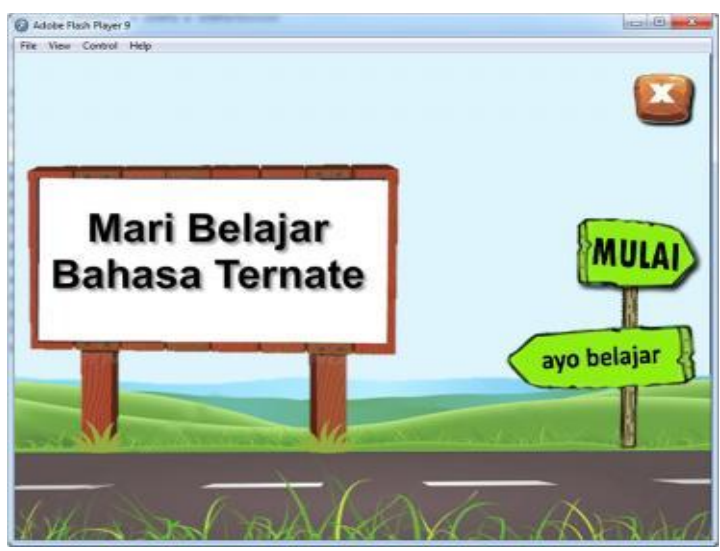

Gambar 14. Form Home

\section{Form Ayo Belajar}

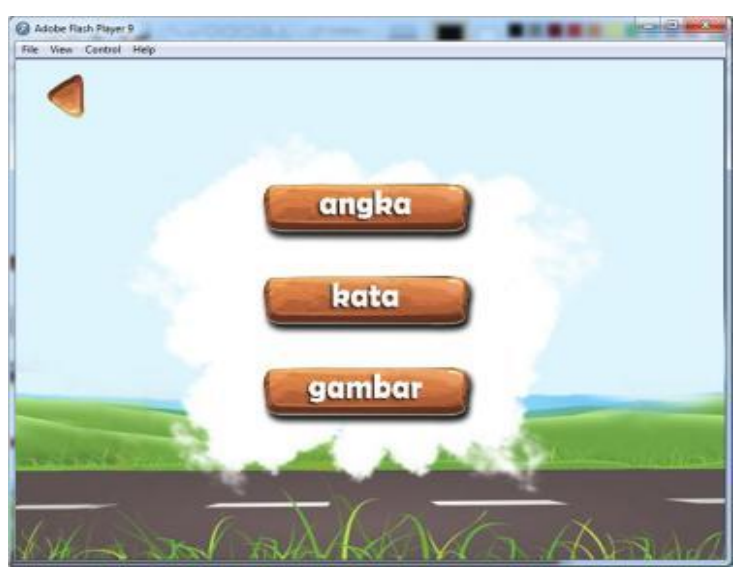

Gambar 15. Form Ayo Belajar

\section{Form Pilih Level}

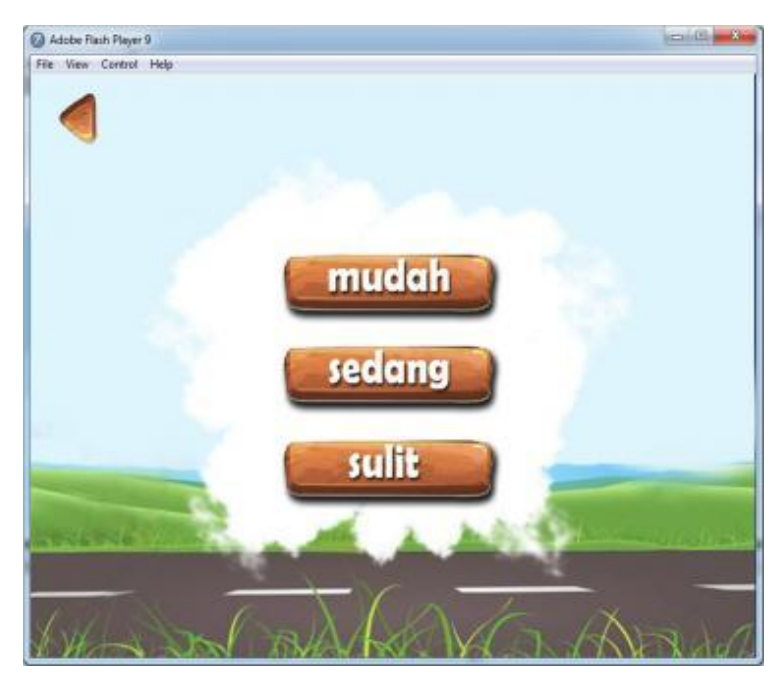

Gambar 16. Form Pilih Level 


\section{Form Kategori}

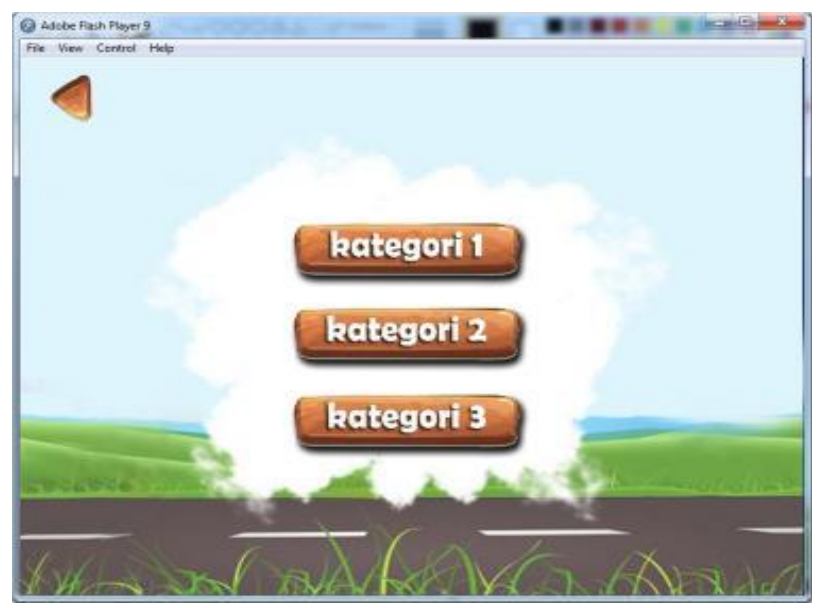

Gambar 17. Form Kategori

\section{Form Score}

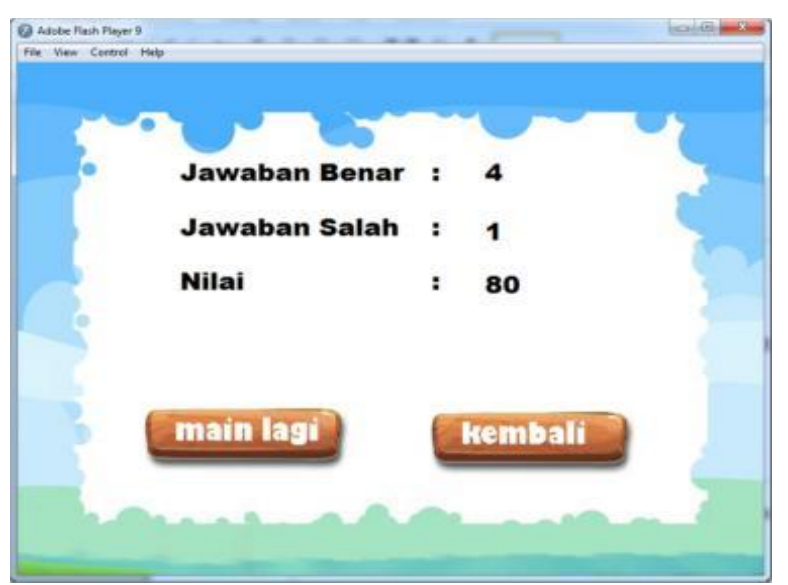

Gambar 18. Form Score

\section{Form Keluar}

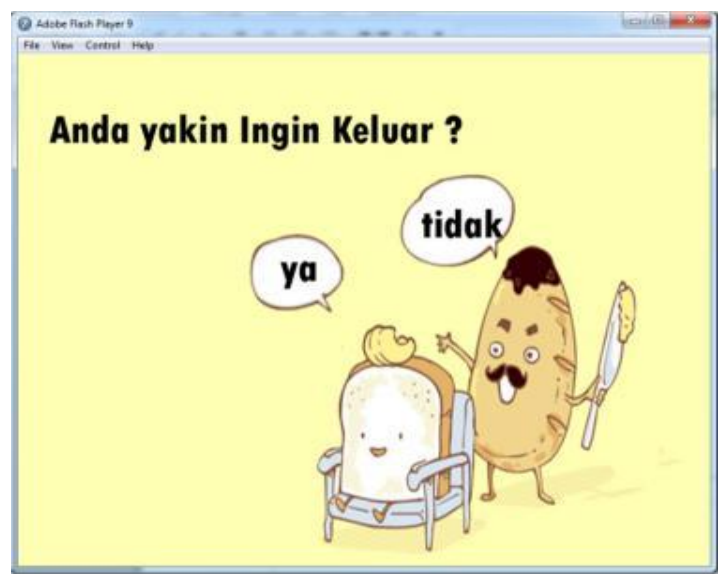

Gambar 19. Form Keluar

\section{Pengujian Sistem}

Game ini merupakan jenis game edukasi atau game pendidikan yang dapat dimanfaatkan sebagai media pembelajaran bagi anak-anak. Pengujian dari game ini menggunakan blackbox, metode ujicoba blackbox memungkinkan pengembangan software untuk membuat himpunan kondisi input yang akan melatih seluruh syarat-syarat fungsional suatu program. Itu sebabnya metode uji coba ini memfokuskan pada keperluan fungsional dari software.

Hasil yang diuji setelah membuka game yaitu mencoba semua tombolbutton dari setiap form, jika tombol button yang diuji benar maka lanjut ke form selajutnya, jika tidak maka tidak bisa lanjut ke form selanjutnya karena buttonnya tidak berfungsi. Pengujian diawali dari halaman awal hingga pengujian skor, disetiap form terdapat button yang bila diklik akan menuju ke tampilan selanjutnya. Form halaman awal terdapat dua button, sama halnya dengan form menu level, form kategori, form petunjuk game, dan form skor. Setiap form mempunyai beberapa button didalamnya yang bila di klik akan menuju ke tampilan selanjutnya, serta ada button kembali dari masing-masing form yang apabila diklik akan kembali ke halaman sebelumnya. Berdasarkan hasil yang dimaksud maka dapat dipastikan bahwa aplikasi atau game yang telah dilakukan pengujian diatas dapat berjalan dengan baik dan benar sesuai dengan yang diinginkan. Pengujian juga dilakukan dengan menguji langsung pada anak-anak dengan kisaran usia rata-rata 10 tahun, hasil yang di dapat dari pengujian tersebut yaitu kebanyakkan dari mereka berhasil menyelesaikan soal dari waktu yang ditentukkan, itu terbukti dari skor permainan yang didapat yakni diatas 70 
yang artinya game ini dapat membantu anak-anak dalam mempelajari bahasa daerah Ternate

\section{KESIMPULAN}

Setelah melakukan pengkajian pokok permasalahan yang diangkat, maka penulis mencoba untuk menarik beberapa kesimpulan yaitu: 1). Game edukasi dapat kita dimanfaatkan sebagai salah satu media untuk memperkenalkan serta mengajarkan bahasa daerah Ternate. Selain itu game ini juga dilengkapi dengan materi pembelajaran serta cara pengucapan dalam bahasa Ternate sehingga anak tidak hanya mengetahui bahasa Ternate saja tetapi juga mengetahui cara pengucapannya dalam bahasa ternate. 2). Aplikasi Game Edukasi Bahasa Daerah Ternate untuk anak-anak yang dibuat menggunakan macromedia flash 8 dalam proses implementasi tersebut berjalan dengan baik, itu dibuktikan dengan adanya pengujian dari beberapa anak dengan kisaran usia rata-rata 10 tahun. 3). Dengan adanya aplikasi game edukasi untuk pembelajaran bahasa Ternate pada anak-anak ini diharapkan dapat membantu dalam meningkatkan pengetahuan anak dalam mengenal bahasa daerah ternate serta melestarikan bahasa daerah tersebut melalui Game.

Berdasarkan kesimpulan sebelumnya, maka dapat diberikan saran untuk pengembangan sebagai berikut: 1). untuk pengembangan berikut dapat ditambahkan database pengguna yang memperoleh nilai tertinggi dan pencapaian waktu dalam permainan. 2). Menu-menu pada Game Edukasi dapat di buat lebih menarik

\section{DAFTAR PUSTAKA}

A.S Rosa \& Shalahudin. M, 2014, Rekayasa Perangkat Lunak, Informatika.
Alfaizi Farhan 2014, Mengenal Berbagai Macam Software, Universitas Tanggerang Banten.

Andreyanto, 2012, Pengenalan Flowchart, Universitas Gunadarma.

Budiman, Agustiar. 2012 Pengujian Perangkat Lunak dengan Metode Black Box Pada Proses Pra Registrasi UserVia Website. Makalah, halaman: 4.

Darmawan Deni, 2014, Sistem Informasi Manajemen

Rosda. Engkus Endang, 2013, Definisi Bahasa Indonesia Sebagai Bahasa Kesatuan dan Bahasa Negara, Depok.

Habiburrahman Azmi, 2011, Apa Itu Macromedia Flash 8?, SMK N 7 Jakarta. Handriyantini,

Eva, 2009. Permainan Edukatif (Educational Games) Berbasis Komputer untuk Siswa Sekolah Dasar Malang, Sekolah Tinggi Informasi \& Komputer Indonesia.

Harsono Ma'aruf, 2014, Pengaruh Bermain Game Terghadap Perkembangan Remaja, Universitas Surya Banten.

Hurd, Daniel dan Jenuings, Erin. 2009. Standardized Educational Games Ratings: Suggested Criteria. Karya Tulis Ilmiah.

Khairunnisa, 2010. Acuan skripsi Perancangan Aplikasi Education Game Untuk Pengajaran Bahasa Inggris Pada Anak-Anak, Universitas Sumatera Utara, 29 Juni 2010.

Mahdi Alim, 2010, Sejarah Flash: Macromedia Flash sebelum Adobe Flash, Bali.

Montessori Maria, edited by Lee Gutek Gerald (2013), Metode Montessori, Yogyakarta: Pustaka Belajar 
Muksin, 2014, Koleksi Game Seru Untuk Kegiatan Belajar Anak, Diva Kids. Nurcahyo Y, 2013. Acuan skripsi

Pembuatan Game Edukasi Bahasa Jawa Petualangan Si Gatot Menggunakan Adobe Flash Cs 4. Universitas STIMIK AMIKOM Yogyakarta.

Periyadi, et, al, 2009, Sistem Komputer, Telkom Polytechnic.

Pressman RS. 2010. Software Engineering: A Practitioner's Approach, 7th ed.Mc Grow Hill.

Putri G. Fatma dewi, 2012. Acuan skripsi Pengembangan Game Pengenalan Nama Hewan Dalam Bahasa Inggris Sebagai Media Pembelajaran Siswa SD Kelas 4 Berbasis Macromedia Flash. Universitas Negeri Yogyakarta.

Qubailatul Isnain Fitriyah, 2012, Kepribadian Anak dari Pola Asuh Ibu yang Authoritarian, Institut Agama Islam Negeri Sunan Ampel, Surabaya.

Rizky, Soetam. 2011. Konsep Dasar Rekayasa Perangkat Lunak. Jakarta: Prestasi Pustaka.

Rusli A. Atjo, 2008, Orang Ternate dan kebudayaannya, Cikoro.

Widuri.raharja.com (diakses 20 Oktober 2015).

Yovi Muhammad, 2015, Pengertian Software (Perangkat Lunak Komputer), Jenis-Jenis Software, dan Pembagian Software.

Winda Angela Hamka, Abdu Gani. Rancang Bagun Game Edukasi Berbasis Web dan Android Menggunakan Adobe Flash CS5 dan Action Script 3.0, IJIS - Indonesian Journal On Information Sistem, Volume 1 Nomor 2 Tahun 2016 